\title{
Ryanodine receptors are involved in muscarinic antinociception in mice
}

\author{
Nicoletta Galeotti*, Alessandro Bartolini, Carla Ghelardini \\ Department of Preclinical and Clinical Pharmacology, University of Florence, Viale G. Pieraccini 6, I-50139 Florence, Italy
}

Received 21 April 2005; received in revised form 9 June 2005; accepted 10 June 2005

Available online 26 July 2005

\begin{abstract}
The role of ryanodine receptors (RyRs) in the induction of muscarinic antinociception was investigated in a condition of acute thermal pain by means of the mouse hot-plate test. I.c.v. administration of non-hyperalgesic doses of ryanodine (0.001-0.06 nmol per mouse i.c.v.), an antagonist of ryanodine receptors (RyRs), dose-dependently prevented the antinociception induced by both physostigmine (100-150 $\mu \mathrm{g} \mathrm{kg}^{-1}$ s.c.) and oxotremorine (40-70 $\mu \mathrm{g} \mathrm{kg}^{-1}$ s.c.). A shift to the right of the dose-response curve of both cholinomimetic compounds was observed. Pretreatment with non-analgesic doses of 4-chloro- $m$-cresol (4-Cmc; $0.003-0.3 \mathrm{nmol}$ per mouse i.c.v.), an agonist of RyRs, reversed in a dosedependent manner the antagonistic effect produced by ryanodine of muscarinic antinociception. The pharmacological treatments employed neither modified the animals' gross behavior nor produced any behavioral impairment of mice as revealed by the rota-rod and hole-board tests. These results indicate that a variation of intracellular calcium contents at the central nervous system level is involved in muscarinic antinociception. In particular, the stimulation of RyRs appears to play an important role in the increase of the pain threshold produced by physostigmine and oxotremorine in mice.
\end{abstract}

(C) 2005 Elsevier B.V. All rights reserved.

Keywords: Ryanodine receptors; Intracellular calcium; Muscarinic antinociception; Pain; Analgesia; Mice

\section{Introduction}

The critical involvement of the cholinergic system in pain inhibitory pathways has long been known. Several reports have also provided evidence for the receptorial mechanism involved in the muscarinic antinociception. Literature data indicates that supraspinal cholinergic antinociception induced both directly, through muscarinic agonists, and indirectly, by enhancing ACh extracellular levels through cholinesterase inhibitors, is mediated by $\mathrm{M}_{1}$ receptor stimulation, evidencing that $\mathrm{M}_{1}$ muscarinic receptor subtype plays an essential role in the modulation of pain perception $[2,11,12,20,23]$. The involvement of the $\mathbf{M}_{2}$ muscarinic receptor subtype in the induction of analgesia has also been postulated by using pharmacological antagonists [13] and by generating $\mathrm{M}_{2}$ muscarinic receptor knockout mice [14].

By contrast, little is known about the post-receptorial events involved in muscarinic antinociception. It is well

\footnotetext{
* Corresponding author. Tel.: +39 055 4271312; fax: +39 0554271280 .

E-mail address: nicoletta.galeotti@unifi.it (N. Galeotti).
}

established that "odd-numbered" muscarinic receptors $\left(\mathrm{M}_{1}-\mathrm{M}_{3}-\mathrm{M}_{5}\right)$ typically couple via the $\alpha$ subunits of the $\mathrm{G}_{\mathrm{q} / 11}$ family to activate phospholipase C (PLC), stimulating phosphoinositide (PI) hydrolysis [4]. Receptor-mediated activation of PLC results in the generation of at least two messengers, inositol-1,4,5-triphosphate ( $\mathrm{InsP}_{3}$ ) and diacylglicerol (DAG). The main effect of DAG is to activate protein kinase $\mathrm{C}$ (PKC); the effect of $\mathrm{InsP}_{3}$ is to release $\mathrm{Ca}^{2+}$ stored in the endoplasmic reticulum. The "even-numbered" members $\left(\mathrm{M}_{2}-\mathrm{M}_{4}\right)$ are preferentially coupled via $\mathrm{G}_{i}$ proteins to inhibit adenylate cyclase [4]. Expression studies revealed that the cloned $\mathrm{m} 2$ and $\mathrm{m} 4$ receptors also stimulate PLC, although with lower efficiency than the PLC stimulation observed by $\mathrm{m} 1$ or $\mathrm{m} 3$ receptors [1].

Calcium ions are widely recognized to play a fundamental role in the regulation of several biological processes. Transient changes in cytoplasmic $\mathrm{Ca}^{2+}$ concentration represent a key step for neurotransmitter release and the modulation of cell membrane excitability. Evidence has accumulated for the involvement of $\mathrm{Ca}^{2+}$ also in nociception and antinociception. On the role of intracellular $\mathrm{Ca}^{2+}$ at a supraspinal 
level, there are several reports indicating its involvement, sometimes opposed, in the mechanism of action of antinociceptive drugs in models of acute pain. It is well documented that agents that increase cytosolic $\mathrm{Ca}^{2+}$ block antinociception induced by $\mu$-opioid agonists when injected intracerebroventricularly (i.c.v.) $[16,25,32,34]$. Furthermore, $\mathrm{Ca}^{2+}$ chelators or antagonists of L-, $\mathrm{N}$ - and P-type $\mathrm{Ca}^{2+}$ channels, potentated $\mu$-opioid receptor-mediated antinociception [25,27]. Conversely, the antinociception produced by selective $\delta$-opioid receptor agonists was potentated by agents that increase intracellular $\mathrm{Ca}^{2+}$ whereas it was reduced by i.c.v. pretreatment with EGTA [25].

The concentration of intracellular $\mathrm{Ca}^{2+}$ is regulated by various mechanisms related to physiological functions. One mechanism is the influx of $\mathrm{Ca}^{2+}$ via $\mathrm{Ca}^{2+}$ channels through the plasma membrane. Another is the release of $\mathrm{Ca}^{2+}$ from intracellular stores via intracellular $\mathrm{Ca}^{2+}$-release channels, the inositol 1,4,5-trisphosphate receptor $\left(\operatorname{Ins}_{3} \mathrm{R}\right)$ and the ryanodine receptor $(\mathrm{RyR})$ : $\operatorname{InsP}_{3} \mathrm{R}$ is a key molecule for $\mathrm{InsP}_{3}$-induced $\mathrm{Ca}^{2+}$ release, whereas $\mathrm{RyR}$ is important for $\mathrm{Ca}^{2+}$-induced $\mathrm{Ca}^{2+}$ release $[7,22]$.

Recently, the involvement of intracellular calcium contents in the supraspinal antinociception produced by cholinomimetic drugs has been investigated. It has been reported that muscarinic antinociception requires the activation of the PLC-InsP $P_{3}$ pathway. In particular, pretreatment with compounds that inhibit the increase of intracellular $\mathrm{Ca}^{2+}$ levels through a blockade of $\mathrm{InsP}_{3} \mathrm{R}$-mediated pathway prevented muscarinic antinociception in mice [9]. However, it should also be taken into account the important role-played by RyRs in the modulation of the intracellular calcium levels. In order to further elucidate the post-receptorial events involved in central muscarinic antinociception, the aim of the present study was to investigate the involvement of RyRs in the mechanism of action of cholinomimetic drugs at a supraspinal level in an animal model of acute thermal pain.

\section{Methods}

\subsection{Animals}

Male Swiss albino mice (22-24g) from Morini (San Polo d'Enza, Italy) were used. Ten mice were housed per cage. The cages were placed in the experimental room $24 \mathrm{~h}$ before the test for acclimatization. The animals were fed a standard laboratory diet and tap water ad libitum and kept at $22 \pm 1{ }^{\circ} \mathrm{C}$ with a $12 \mathrm{~h}$ light/dark cycle, light at 7 a.m. All experiments were carried out in accordance with the NIH Guide for the Care and Use of Laboratory animals. All efforts were made to minimize animal suffering, and to reduce the number of animals used.

\subsection{Hot-plate test}

The method adopted was described by O'Callaghan and Holtzman [24]. Mice were placed inside a stainless steel container, which was set thermostatically at $52.5 \pm 0.1^{\circ} \mathrm{C}$ in a precision water-bath from KW Mechanical Workshop, Siena, Italy. Reaction times (s), were measured with a stopwatch before and 15, 30, 45 and $60 \mathrm{~min}$ after administration of analgesic drugs. The endpoint used was the licking of the fore or hind paws. Those mice scoring less than 12 and more than $18 \mathrm{~s}$ in the pretest were rejected (30\%). An arbitrary cutoff time of $45 \mathrm{~s}$ was adopted. No sign of tissue injury was observed up to $45 \mathrm{~s}$. At least two independent replications of 7 mice each were performed (14 mice per treatment).

\subsection{Rota-rod test}

The apparatus consisted of a base platform and a rotating rod with a diameter of $3 \mathrm{~cm}$ and a non-slippery surface. The rod was placed at a height of $15 \mathrm{~cm}$ from the base. The rod, $30 \mathrm{~cm}$ in length, was divided into 5 equal sections by 6 disks. Thus, up to 5 mice were tested simultaneously on the apparatus, with a rod-rotating speed of $16 \mathrm{rpm}$. The integrity of motor coordination was assessed on the basis of the number of falls from the rod in $30 \mathrm{~s}$ according to Vaught et al. [33]. Those mice scoring less than 3 and more than 6 falls in the pretest were rejected $(20 \%)$. The performance time was measured before (pretest) and 15, 30 and 45 min after the beginning of the test. Ten mice per group were tested.

\subsection{Hole-board test}

The hole-board test consisted of a $40 \mathrm{~cm}$ square plane with 16 flush mounted cylindrical holes $(3 \mathrm{~cm}$ diameter) distributed $4 \times 4$ in an equidistant, grid-like manner. Mice were placed on the center of the board one by one and allowed to move about freely for a period of $5 \mathrm{~min}$ each. Two electric eyes, crossing the plane from mid-point to mid-point of opposite sides, thus dividing the plane into 4 equal quadrants, automatically signaled the movement of the animal (counts in $5 \mathrm{~min}$ ) on the surface of the plane (spontaneous motility). Miniature photoelectric cells, in each of the 16 holes, recorded (counts in $5 \mathrm{~min}$ ) the exploration of the holes (exploratory activity) by the mice. Ten mice per group were tested.

\subsection{I.c.v. injection technique}

I.c.v. administration was performed under ether anesthesia with isotonic saline as solvent, according to the method described by Haley and McCormick [15]. During anesthesia, mice were grasped firmly by the loose skin behind the head. A hypodermic needle ( $0.4 \mathrm{~mm}$ external diameter) attached to a $10 \mu \mathrm{l}$ syringe was inserted perpendicularly through the skull and no more than $2 \mathrm{~mm}$ into the brain of the mouse, where $5 \mu$ l solution were then administered. The injection site was $1 \mathrm{~mm}$ to the right or left from the midpoint on a line drawn through to the anterior base of the ears. Injections were performed randomly into the right or left ventricle. To ascertain that solutions were administered exactly into the cerebral ventricle, some mice were injected with $5 \mu l$ of diluted 1:10 India ink and their brains were examined macroscopically after sectioning. The accuracy of the injection technique was evaluated with $95 \%$ of injections being correct.

\subsection{Drugs}

The following drugs were used: ryanodine, 4-chloro- $m$ cresol, (Calbiochem, Milan Italy); physostigmine hemisulphate, 
oxotremorine methiodide (Sigma, Milan, Italy). Other chemicals were of the highest quality commercially available.

4-Chloro-m-cresol (4-Cmc) was dissolved in $0.5 \%$ ethanol whereas all other drugs were dissolved in isotonic $(\mathrm{NaCl} 0.9 \%)$ saline solution immediately before use. Drug concentrations were prepared so that the necessary dose could be administered in a volume of $5 \mu \mathrm{l}$ per mouse by intracerebroventricular (i.c.v.) injection and $10 \mathrm{ml} \mathrm{kg}^{-1}$ by subcutaneous (s.c.) injection.

\subsection{Statistical analysis}

All experimental results are given as the mean \pm S.E.M. An analysis of variance ANOVA, followed by Fisher's protected least significant difference procedure for post hoc comparison, were used to verify significance between two means of behavioral results. Data were analyzed with the StatView software for the Macintosh (1992). $P$-values of less than 0.05 were considered significant.

\section{Results}

\subsection{Prevention by ryanodine of muscarinic antinociception}

The effect of the RyR antagonist ryanodine on muscarinic antinociception against an acute thermal stimulus was evaluated by means of the mouse hot-plate test.

Physostigmine, administered at the dose of $100 \mu \mathrm{g} \mathrm{kg}^{-1}$ s.c. induced an antinociceptive effect, which was prevented by i.c.v. administration of ryanodine in a dose-dependent manner. The doses of 0.001 and $0.01 \mathrm{nmol}$ per mouse i.c.v. were devoid of any effect. At $0.03 \mathrm{nmol}$ per mouse i.c.v. ryanodine produce a reduction of the licking latency, which did not reach the statistical significance, whereas at $0.06 \mathrm{nmol}$ per mouse i.c.v ryanodine antagonized the increase of the pain threshold. Similarly, ryanodine at $0.06 \mathrm{nmol}$ per mouse i.c.v. prevented the antinociception induced by physostigmine injected at the dose of $150 \mu \mathrm{g} \mathrm{kg}^{-1}$ s.c. (Fig. 1A). A shift to the right of the dose-response curve of physostigmine by administration of ryanodine at $0.06 \mathrm{nmol}$ per mouse i.c.v. is reported in Fig. 1B.

Oxotremorine (40-70 $\mu \mathrm{g} \mathrm{kg}^{-1}$ s.c.) increase the licking latency values in the mouse hot-plate test. Pretreatment with ryanodine dose-dependently prevented this antinociceptive effect. Ryanodine administered at the dose of $0.001 \mathrm{nmol}$ per mouse i.c.v. was unable to modify the oxotremorineinduced antinociception whereas, at the dose of $0.06 \mathrm{nmol}$ per mouse i.c.v. it produced a statistically significant prevention of the oxotremorine-induced increase of the pain threshold (Fig. 2A). A shift to the right of the dose-response curve of oxotremorine by administration of ryanodine at $0.06 \mathrm{nmol}$ per mouse i.c.v. is reported in Fig. 2B.

Ryanodine, at the dose of $0.06 \mathrm{nmol} /$ mouse i.c.v., was unable to prevent the analgesia induced by diphenhydramine $20 \mathrm{mg} \mathrm{kg}^{-1}$ s.c. (diph. + saline: $28.4 \pm 3.3$; diph. + ryan.: $29.8 \pm 2.9$ ) and by baclofen $4 \mathrm{mg} \mathrm{kg}^{-1}$ s.c. (bacl. + saline: $33.0 \pm 2.0$; bacl. + ryan: $32.1 \pm 3.5$ ).
Ryanodine, when injected alone at the highest effective dose $(0.06 \mathrm{nmol}$ per mouse i.c.v.) was unable to modify the licking latency values of animals in comparison with salinetreated control group (Fig. 1A).

The licking latency values reported in Figs. 1 and 2 were recorded in correspondence with physostigmine and oxotremorine maximum effect (15 min after administration) as evidenced by time-course experiments performed in our laboratory (data not shown).

\subsection{Reversal of 4-Cmc of the ryanodine-induced antagonistic effect on muscarinic antinociception}

The administration of the RyR agonist 4-Cmc (0.003$0.1 \mathrm{nmol}$ per mouse i.c.v.) produced a dose-dependent reversal of the antagonistic effect induced by pretreatment with ryanodine of the muscarinic antinociception (Figs. 3 and 4). The licking latency values reported in the figure were recorded $120 \mathrm{~min}$ after administration of 4-Cmc in correspon-
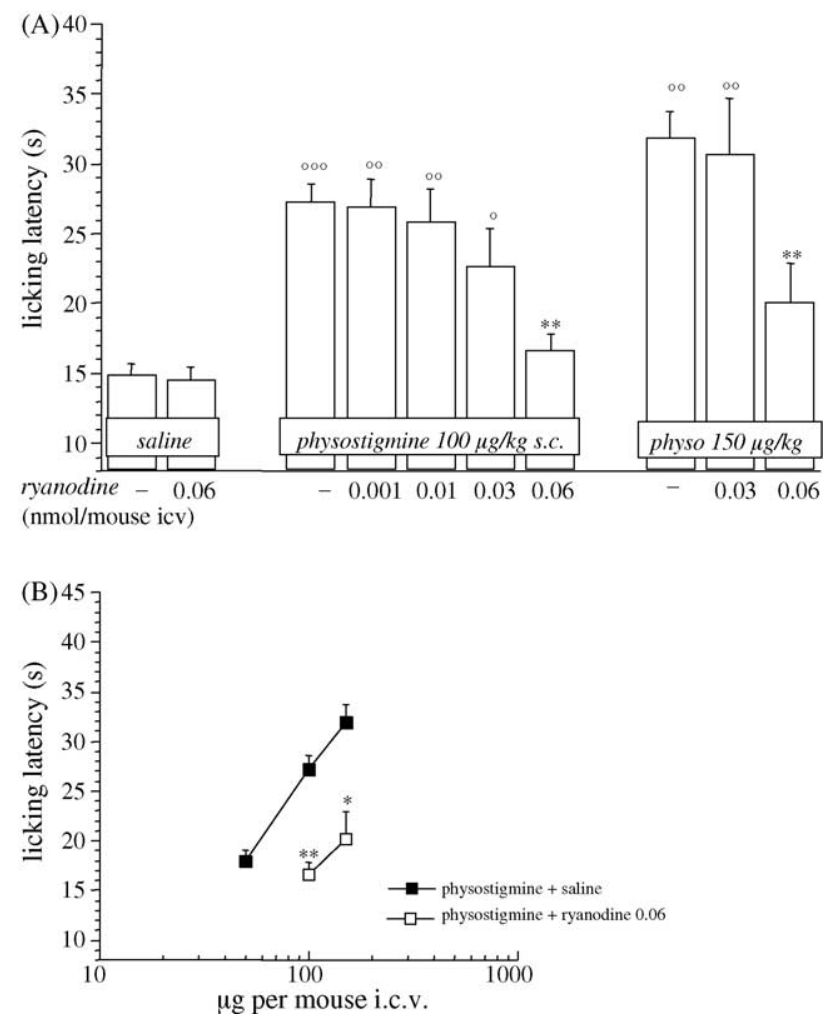

Fig. 1. Panel A: dose-response curve of the antagonism produced by ryanodine $(0.001-0.06 \mathrm{nmol}$ per mouse i.c.v.) of the antinociception induced by physostigmine $\left(100-150 \mu \mathrm{g} \mathrm{kg}^{-1}\right.$ s.c.) in the mouse hot-plate test. The licking latency values were recorded $15 \mathrm{~min}$ after physostigmine administration. Vertical lines represent S.E.M. ${ }^{\circ} P<0.05,{ }^{\circ} P<0.01,{ }^{\circ} P(P<0.001$ in comparison with saline-treated group; ${ }^{* *} P<0.01$ in comparison with physostigmine-treated group. Panel B: shift to the right of the dose-response curve of physostigmine by ryanodine $0.06 \mathrm{nmol}$ per mouse i.c.v. in the mouse hot-plate test. The licking latency value were recorded $15 \mathrm{~min}$ after physostigmine administration. Vertical lines represent S.E.M. ${ }^{*} P<0.05$, ${ }^{* *} P<0.01$ in comparison with physostigmine-treated group. 

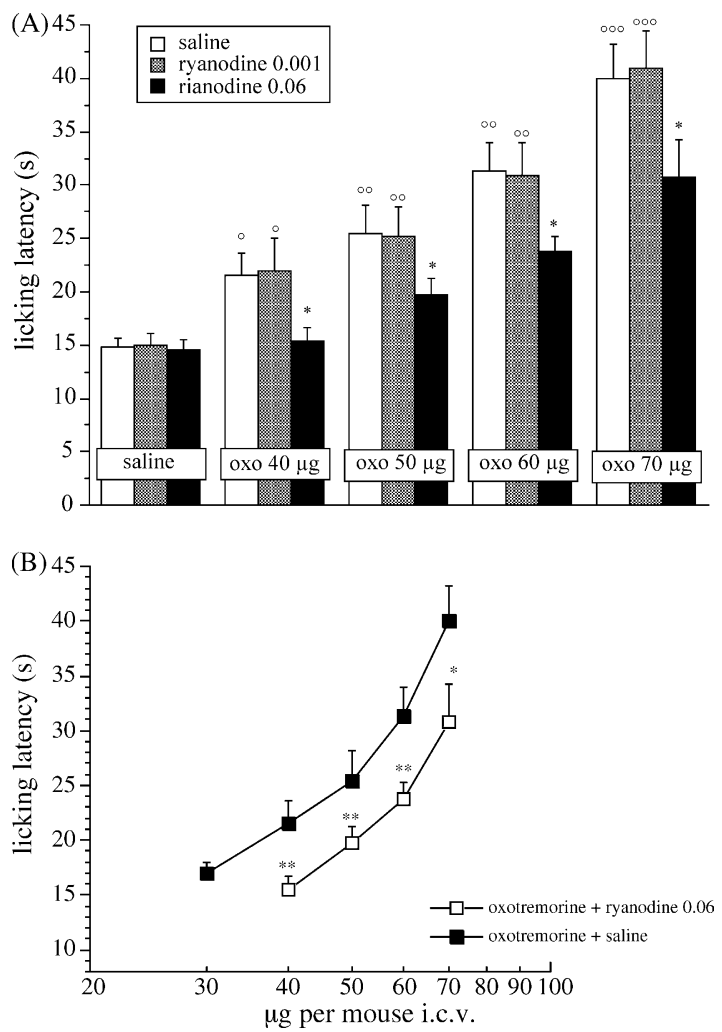

Fig. 2. Panel A: dose-response curve of the antagonism produced by ryanodine $(0.001-0.06 \mathrm{nmol}$ per mouse i.c.v.) of the antinociception induced by oxotremorine $\left(40-70 \mu \mathrm{g} \mathrm{kg}^{-1}\right.$ s.c.) in the mouse hot-plate test. The licking latency value were recorded $15 \mathrm{~min}$ after oxotremorine administration. Vertical lines represent S.E.M. ${ }^{\circ} P<0.05,{ }^{\circ} P<0.01,{ }^{\circ 0} P<0.001$ in comparison with saline-treated group; ${ }^{*} P<0.05,{ }^{* *} P<0.01$ in comparison with oxotremorine-treated group. Panel B: shift to the right of the dose-response curve of oxotremorine by ryanodine $0.06 \mathrm{nmol}$ per mouse i.c.v. in the mouse hot-plate test. The licking latency value were recorded $15 \mathrm{~min}$ after oxtremorine administration. Vertical lines represent S.E.M. ${ }^{*} P<0.05,{ }^{* *} P<0.01$ in comparison with oxotremorine-treated group.

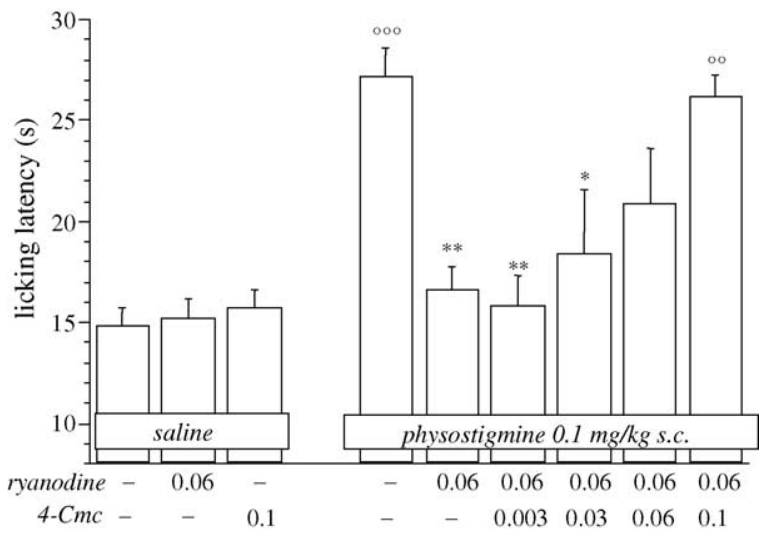

Fig. 3. Reversal by 4-Cl- $m$-cresol (4-Cmc) of the antagonism produced by ryanodine $\left(0.06 \mathrm{nmol}\right.$ per mouse i.c.v.) of the physostigmine $\left(100 \mu \mathrm{g} \mathrm{kg}^{-1}\right.$ s.c.)-induced antinociception. Vertical lines represent S.E.M. ${ }^{\circ} P<0.01$, ${ }^{\circ 00} P<0.001$ in comparison with saline-treated group; ${ }^{*} P<0.05,{ }^{* *} P<0.01$ in comparison with physostigmine-treated group.

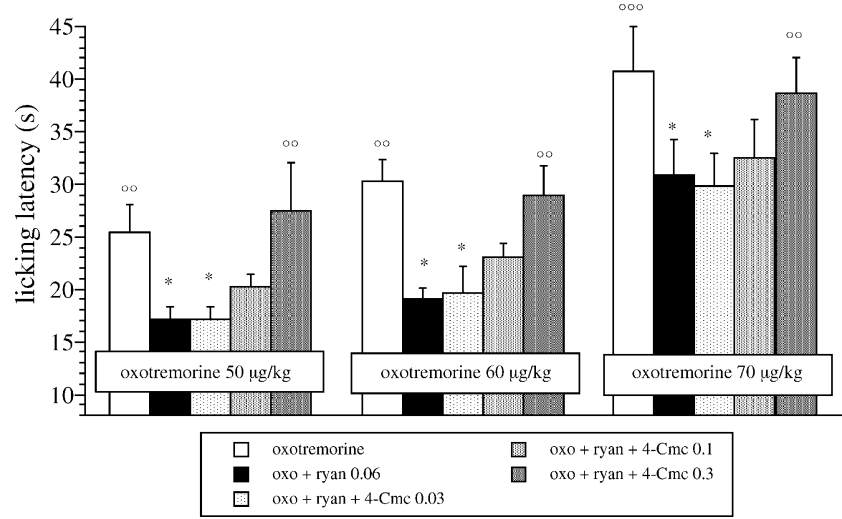

Fig. 4. Reversal by 4-Cl-m-cresol (4-Cmc) of the antagonism produced by ryanodine $\left(0.06 \mathrm{nmol}\right.$ per mouse i.c.v.) of the oxotremorine $\left(50-70 \mu \mathrm{g} \mathrm{kg}^{-1}\right.$ s.c.)-induced antinociception. Vertical lines represent S.E.M. ${ }^{\circ} P<0.01$, ${ }^{000} P<0.001$ in comparison with saline-treated group; ${ }^{*} P<0.05$ in comparison with oxotremorine-treated group.

dence with its maximum effect as evidenced by time-course experiments (data not shown).

The doses of 4-Cmc of 0.003 and $0.03 \mathrm{nmol}$ per mouse i.c.v. were completely ineffective on modifying the antagonism induced by ryanodine $(0.06 \mathrm{nmol}$ per mouse i.c.v $)$ of physostigmine $\left(100 \mu \mathrm{g} \mathrm{kg}^{-1}\right.$ s.c.) antinociception. The dose of $4-\mathrm{Cmc}$ of $0.06 \mathrm{nmol}$ per mouse i.c.v. produced a partial reversal without reaching the statistical significance, whereas the dose of $0.1 \mathrm{nmol}$ per mouse i.c.v. reversed the ryanodineinduced antagonism of the physostigmine-induced antinociceptive effect (Fig. 2). Similarly, 4-Cmc dose-dependently reversed the prevention of the antagonism of oxotremorine (50, 60 and $70 \mu \mathrm{g} \mathrm{kg}^{-1}$ s.c.) antinociception by pretreatment with ryanodine. The dose of $4-\mathrm{Cmc}$ of $0.03 \mathrm{nmol}$ was devoid of any effect, the dose of $0.1 \mathrm{nmol}$ per mouse i.c.v. produced a non-significant partial reversal, whereas at $0.3 \mathrm{nmol}$ per mouse i.c.v. abolished the antagonism produced by ryanodine (Fig. 4).

4-Cmc, when injected alone at the highest doses investigated did not modify the pain threshold of animals in comparison with the control group (Fig. 3).

\subsection{Effect of treatments on mouse behaviour}

The compounds investigated, at the highest effective doses, were tested in order to assess their effect on mouse behavior. Mice pretreated with ryanodine $(0.06 \mathrm{nmol}$ per mouse i.c.v.), $4-\mathrm{Cmc}(0.3 \mathrm{nmol}$ per mouse i.c.v.), physostigmine $\left(150 \mu \mathrm{g} \mathrm{kg}^{-1}\right.$ s.c. $)$ and oxotremorine $\left(70 \mu \mathrm{g} \mathrm{kg}^{-1}\right.$ s.c. $)$ were evaluated for motor coordination by use of the rota-rod test, and for spontaneous motility and inspection activity by use of the hole-board test.

The spontaneous motility as well as the inspection activity of mice, expressed as counts in $10 \mathrm{~min}$, were unmodified by pretreatment with ryanodine, $4-\mathrm{Cmc}$, physostigmine and oxotremorine in comparison with control group (Fig. 5). 


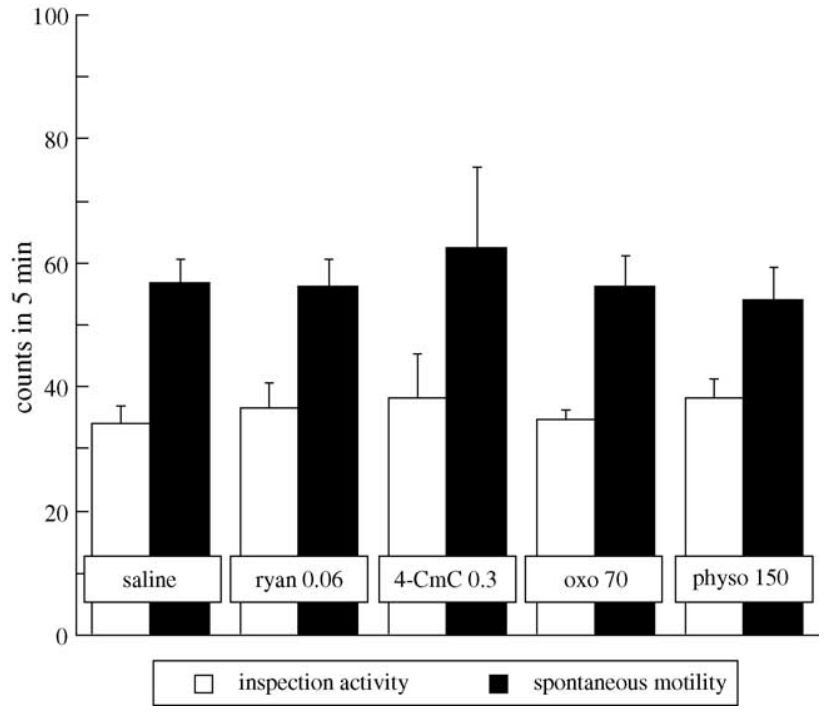

Fig. 5. Lack of effect by ryanodine $(0.06 \mathrm{nmol}$ per mouse i.c.v. $)$, 4Cmc $\left(0.03 \mathrm{nmol}\right.$ per mouse i.c.v.), physostigmine $\left(150 \mu \mathrm{g} \mathrm{kg}^{-1}\right.$ s.c. $)$ and oxotremorine $\left(70 \mu \mathrm{g} \mathrm{kg}^{-1}\right.$ s.c.) on spontaneous motility and inspection activity in the mouse hole-board test. Vertical lines represent S.E.M. 4-Cmc was injected $105 \mathrm{~min}$ before the beginning of the test, whereas ryanodine, physostigmine and oxotremorine were administered $15 \mathrm{~min}$ before the beginning of the test.

The number of falls from the rotating rod, evaluated before and 15,30 and 45 min after the beginning of the rota-rod test, showed the lack of any impairment in the motor coordination of animals pretreated with all pharmacological modulators in comparison with the control group (Fig. 6).

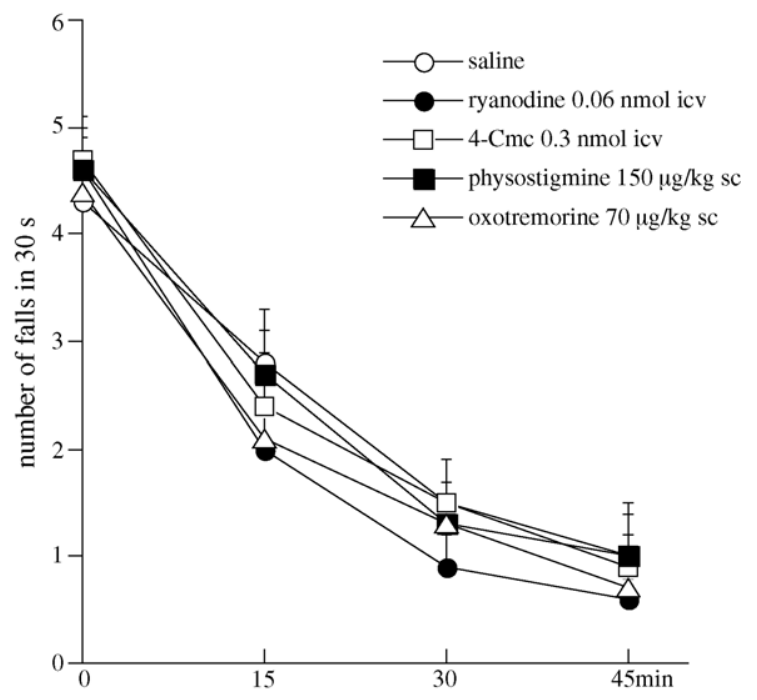

Fig. 6. Lack of effect by ryanodine $(0.06 \mathrm{nmol}$ per mouse i.c.v. $)$, 4$\mathrm{Cmc}\left(0.03 \mathrm{nmol}\right.$ per mouse i.c.v.), physostigmine $\left(150 \mu \mathrm{g} \mathrm{kg}^{-1}\right.$ s.c.) and oxotremorine ( $70 \mu \mathrm{g} \mathrm{kg}^{-1}$ s.c.) on motor coordination in the mouse rota-rod test. Vertical lines represent S.E.M. 4-Cmc was injected $105 \mathrm{~min}$ before the beginning of the test, whereas ryanodine, physostigmine and oxotremorine were administered $15 \mathrm{~min}$ before the beginning of the test. Vehicle: $0.5 \%$ ethanol.

\section{Discussion}

The present study investigated the role of ryanodine receptors in the supraspinal muscarinic antinociception in a condition of acute thermal pain in mice. The importance of the activation of the RyR-mediated pathway to obtain an increase of the pain threshold by cholinomimetic drugs was evidenced.

$\mathrm{Ca}^{2+}$ plays an important role in a variety of central and peripheral physiological processes. To avoid the possible appearance of peripheral effects that could lead to a misinterpretation of the results obtained, the $\mathrm{Ca}^{2+}$ modulators used in the present study were administered directly into the cerebral ventricles.

The release of $\mathrm{Ca}^{2+}$ from intracellular stores is mediated via intracellular $\mathrm{Ca}^{2+}$-release channels, the inositol 1,4,5trisphosphate receptor $\left(\operatorname{InsP}_{3} \mathrm{R}\right)$ and the ryanodine receptor (RyR): $\mathrm{InsP}_{3} \mathrm{R}$ is a key molecule for $\mathrm{InsP}_{3}$-induced $\mathrm{Ca}^{2+}$ release, whereas RyR is important for $\mathrm{Ca}^{2+}$-induced $\mathrm{Ca}^{2+}$ release. The involvement of $\operatorname{Ins}_{3} \mathrm{R}$ in the mechanism of analgesic action of cholinomimetics has already been observed [9]. Since both receptor subtypes are involved in intracellular calcium mobilization, in the present study the role played by RyRs in muscarinic antinociception was investigated.

The i.c.v. administration of ryanodine produced a dose-dependent prevention of the physostigmine- and oxotremorine-induced antinociception in mice. A shift to the right of the dose-response curve of both cholinomimetic drugs was observed. These data indicate the involvement of RyRs in the induction of muscarinic antinociception. Present results are in agreements with previous literature reports indicating the involvement of RyRs in the mechanism of action of analgesic drugs. Ohsawa et al. [25] showed that ryanodine reduced the antinociception induced by the delta opioid agonist (-)-TAN67 in diabetic mice. It has been reported that ryanodine blocks $\mathrm{Ca}^{2+}$ release from $\mathrm{Ca}^{2+} /$ caffeine-sensitive microsomal pools, which are involved in the phenomenon of $\mathrm{Ca}^{2+}$-induced $\mathrm{Ca}^{2+}$ release [21]. Ryanodine reduces the rate at which $\left[\mathrm{Ca}^{2+}\right]_{\mathrm{i}}$ increase with $\mathrm{Ca}^{2+}$ entry [8]. Thus, it seems likely that the antagonism of the cholinomimetic drug-induced antinociception produced by i.c.v. ryanodine might be due to a decrease of $\left[\mathrm{Ca}^{2+}\right]_{i}$ at supraspinal level. Physostigmine, acting as a cholinesterase inhibitor, produces an increase of the ACh levels, which, on their turn, can activate both muscarinic and nicotinic receptors. It has been reported that nicotinic antinociception depends on an increase of the intracellular calcium contents. Pretreatment with calcium, BAYK8644 and thapsigargin, compounds that increase the intracellular calcium levels, potentated nicotineinduced antinociception, whereas agents that decrease intracellular calcium blocked the increase of the pain threshold induced by nicotine [6]. Furthermore, the nicotine-evoked calcium response in SH-SY5Y is blocked by ryanodine and xestospongin $\mathrm{C}$ (an antagonist of $\mathrm{Ins}_{3} \mathrm{R}$ ) indicating that it involves calcium release from ryanodine and $\mathrm{InsP}_{3}$ dependent intracellular stores [5]. However, ryanodine, in our experimental conditions prevented not only physostigmine- 
induced but also oxotremorine-induced increase of pain threshold suggesting that the release of $\mathrm{Ca}^{2+}$ from intracellular stores produced by RyR activation is necessary to induce muscarinic antinociception. It should also be noted that an increased intracellular calcium mobilization through RyR activation has been demonstrated after stimulation of muscarinic receptors. Carbachol-evoked increase of intracellular calcium concentration in cerebellar granule cells was inhibited by ryanodine [30]. Activation of muscarinic acetylcholine receptors in NG108-15 neuroblastoma $\times$ glioma cells produces cyclic ADP-ribose, a known endogenous modulator of RyR, which may upregulate the release of calcium from the ryanodine receptors $[18,19]$. Carbachol-induced contractions of rat stomach fundus strips were reduced by ryanodine and thapsigargin [31]. Similarly, ryanodine blocked the early contraction component increased by carbachol in guinea pig ventricular myocytes [28].

The prevention of physostigmine and oxotremorine antinociception produced by ryanodine was dosedependently reversed by co-administration of chloro- $m$ cresol (4-Cmc), an agonist of RyR [17], further suggesting the involvement of RyRs in muscarinic antinociception. It should also be taken into account that compounds able to activate RyR, such as caffeine, are endowed with central antinociceptive properties [10,26,29].

The highest active doses of ryanodine used in the present study, in the absence of co-administration of analgesic drugs, did not reduce the pain threshold of mice in comparison with control groups. These results exclude that the prevention of physostigmine and oxotremorine antinociception is due to an hyperalgesic effect of ryanodine. Pretreatment with ryanodine was unable to modify the analgesia induced by the antihistamine diphenhydramine and the $\mathrm{GABA}_{\mathrm{B}}$ agonist baclofen ruling out that the ryanodine-induced antagonism of muscarinic antinociception might underlie to an hypernociceptive effect of ryanodine only detectable in the presence of an increased pain threshold. Finally, 4-Cmc, that reversed the antagonism induced by ryanodine, when injected alone, did not increase the mouse pain threshold and, therefore, excluding that the action produced by $4-\mathrm{Cmc}$ on muscarinic analgesia origins from antinociceptive properties of the RyR agonist employed.

The receptor-mediated activation of the muscarinic system, as well as the modulation of the intracellular events promoted by cholinomimetics, can induce several side effects. It is widely known that physostigmine and oxotremorine can produce the typical cholinergic symptomatology (tremors, sialorrhea, diarrhea, lacrimation, etc.). Cytosolic $\mathrm{Ca}^{2+}$ regulates numerous neuronal functions [3] and, therefore, a variation of intracellular $\mathrm{Ca}^{2+}$ contents can induce behavioural side effects. Both cholinomimetic drugs and RyR modulators, at the highest active doses employed in the present study, did not cause any detectable modification in mouse gross behavior. At the same doses, all treatments did not impair motor coordination nor modify spontaneous motility nor inspection activity in comparison with control groups excluding that the results obtained were due to animals' altered viability. It should be noted that higher doses of cholinomimetics could not be investigated since they induced toxicity (tremors, convulsions, etc.) in animals.

Seen as a whole present results indicate that the variation of cytosolic $\mathrm{Ca}^{2+}$ contents at supraspinal level by modulating RyR is involved in the muscarinic antinociception evaluated in an acute thermal pain paradigm. In particular, a decrease of cytosolic $\mathrm{Ca}^{2+}$ through the blocked of RyR prevents muscarinic antinociception whereas an increase of intracellular $\mathrm{Ca}^{2+}$ induced by RyR activation restores the sensitivity to cholinomimetic drugs of animal pretreated with a RyR antagonist.

\section{References}

[1] Ashkenazi A, Winslow JW, Peralta EG, Peterson GL, Schimerlik MI, Capon DJ, et al. An $\mathrm{m} 2$ muscarinic receptor subtype coupled to both adenylyl cyclase and phosphoinositide turnover. Science 1987;238:672-5.

[2] Bartolini A, Ghelardini C, Fantetti L, Malcangio M, MalmbergAiello P, Giotti A. Role of muscarinic receptor subtypes in central antinociception. Br J Pharmacol 1992;105:77-82.

[3] Berridge MJ. Neuronal calcium signaling. Neuron 1998;21:13-26.

[4] Caulfield MP, Birdsall NJM. International Union of Pharmacology. XVII. Classification of muscarinic acetylcholine receptors. Pharmacol Rev 1998;50:279-90.

[5] Dajas-Bailador FA, Mogg AJ, Wonnacott S. Intracellular $\mathrm{Ca}^{2+}$ signals evoked by stimulation of nicotine acetylcholine receptors in SH-SY5Y cells: contribution of voltage-operated $\mathrm{Ca}^{2+}$ channels and $\mathrm{Ca}^{2+}$ stores. J Neurochem 2002;81:606-14.

[6] Damaj MI, Welch SP, Martin BR. Involvement of calcium and Ltype channels in nicotine-induced antinociception. J Pharmacol Exp Ther 1993;266:1330-8.

[7] Fill M, Copello JA. Ryanodine receptor calcium release channels. Physiol Rev 2002;82:893-922.

[8] Friel DD, Tsien RW. A caffeine-and ryanodine-sensitive $\mathrm{Ca}^{2+}$ store in bullfrog sympathetic neurons modultes effects of $\mathrm{Ca}^{2+}$ entry on $\left[\mathrm{Ca}^{2+}\right]$. J Physiol 1992;450:217-46.

[9] Galeotti N, Bartolini A, Ghelardini C. The phospholipase C-IP 3 pathway is involved in muscarinic antinociception. Neuropsychopharmacology 2003;28:888-97.

[10] Ghelardini C, Galeotti N, Bartolini A. Caffeine induces central cholinergic analgesia. N-S Arch Pharmacol 1997;356:590-5.

[11] Ghelardini C, Galeotti N, Bartolini A. Loss of muscarinic antinociception by antisense inhibition of $\mathrm{M}_{1}$ receptors. Br $\mathrm{J}$ Pharmacol 2000;129:1633-40.

[12] Ghelardini C, Galeotti N, Gualtieri F, Romanelli MN, Bartolini A. S-(-)-ET126: a potent and selective $\mathrm{M}_{1}$ antagonist in vivo and in vitro. Life Sci 1996;58:991-1000.

[13] Gillbert PG, Gordh Jr T, Hartvig P, Jansson I, Petterson J, Post C. Characterization of the antinociception induced by intrathecally administered carbachol. Pharmacol Toxicol 1989;64:340-3.

[14] Gomeza J, Zhang L, Kostenis E, Felder CC, Bymaster FP, Brodkin $\mathrm{J}$, et al. Generation and pharmacological analysis of $\mathrm{M}_{2}$ and $\mathrm{M}_{4}$ muscarinic receptor knockout mice. Life Sci 2001;68:2457-66.

[15] Haley TJ, McCormick WG. Pharmacological effects produced by intracerebral injection of drugs in the conscious mouse. Br J Pharmacol Chemother 1957;12:12-5.

[16] Harris RA, Loh HH, Way EL. Effects of divalent cations, cation chelators and an ionophore on morphine analgesia and tolerance. J Pharmacol Exp Ther 1975;195:488-98. 
[17] Herrmann-Frank A, Varsanyi M. Enhancement of $\mathrm{Ca}^{2+}$ release channel activity by phosphorylation of the skeletal muscle ryanodine receptor. FEBS Lett 1993;332:237-42.

[18] Higashida H, Yokoyama S, Hashii M, Taketo M, Higashida M, Takayasu T, et al. Muscarinic receptor-mediated dual regulation of ADP-ribosyl cyclase in NG108-15 neuronal cell membranes. J Biol Chem 1997;272:31272-7.

[19] Higashida H, Yokoyama S, Hoshi N, Hashii M, Egorova A, Zhong $\mathrm{ZG}$, et al. Signal transduction from bradykinin, angiotensin, adrenergic and muscarinic receptors to effector enzymes, including ADPribosyl cyclase. Biol Chem 2001;382:23-30.

[20] Iwamoto ET, Marion L. Characterization of the antinociception produced by intrathecally administered muscarinic agonists in rats. J Pharmacol Exp Ther 1993;266:329-38.

[21] McPherson PS, Kim YK, Valdivia H, Knudson CM, Takekura $\mathrm{H}$, Franzini-Armstrong $\mathrm{C}$, et al. The brain ryanodine receptor: a caffeine-sensitive calcium release channel. Neuron 1991;7:17-25.

[22] Mikoshiba K. The InsP3 receptor and intracellular $\mathrm{Ca}^{2+}$ signaling. Curr Opin Neurobiol 1997;7:339-45.

[23] Naguib M, Yaksh TL. Characterization of muscarinic receptor subtypes that mediate antinociception in the rat spinal cord. Anesth Analg 1997;85:847-53.

[24] O'Callaghan JP, Holtzman SG. Quantification of the analgesic activity of narcotic antagonists by a modified hot-plate procedure. J Pharmacol Exp Ther 1975;192:497-505.

[25] Ohsawa M, Nagase H, Kamei J. Role of intracellular calcium in modification of mu and delta opioid receptor-mediated antinociception by diabetes in mice. J Pharmacol Exp Ther 1998;286: 780-7.
[26] Person DL, Kissin I, Brown PT, Xavier AV, Vinik HR, Bradley EL. Morphine-caffeine analgesic interaction in rats. Anesth Analg 1985;64:851-6.

[27] Prado WA. Involvement of calcium in pain and antinociception. Braz J Med Biol Res 2001;34:449-61.

[28] Protas L, Shen JB, Pappano AJ. Carbachol increases contractions and intracellular $\mathrm{Ca}^{++}$transients in guinea pig ventricular myocytes. J Pharmacol Exp Ther 1998;284:66-74.

[29] Sawynok J, Reid AR, Doak GJ. Caffeine antinociception in the rat hot-plate and formaline tests and locomotor stimulation: involvement of noradrenergic mechanisms. Pain 1995;61:203-7.

[30] Simpson PB, Nahorski SR, Challiss RA. Agonist-evoked $\mathrm{Ca}^{2+}$ mobilization from stores expressing inositol 1,4,5-trisphosphate receptors and ryanodine receptors in cerebellar granule neurones. J Neurochem 1996;67:364-73.

[31] Smaili SS, Carvalho SM, Cavalcanti PM, Jurkiewicz NH, Garcia AG, Jurkiewicz A. Intracellular calcium mobilization by muscarinic receptors is regulated by micromolar concentrations of external $\mathrm{Ca}^{2+}$. Pflug Arch 2001;442:376-82.

[32] Smith FL, Stevens DL. Calcium modulation of morphine analgesia: role of calcium channels and intracellular pool calcium. J Pharmacol Exp Ther 1995;272:290-9.

[33] Vaught J, Pelley K, Costa LG, Sether P, Enna SJ. A comparison of the antinociceptive responses to GABA-receptor agonists THIP and baclofen. Neuropharmacology 1985;24:211-6.

[34] Vocci Jr FJ, Welch SP, Dewey WL. Differential effects of divalent cations, cation chelators and an ionophore (A23187) on morphine and dibutyryl guanosine $3^{\prime}: 5^{\prime}$-cyclic monophosphate antinociception. J Pharmacol Exp Ther 1980;21:463-6. 